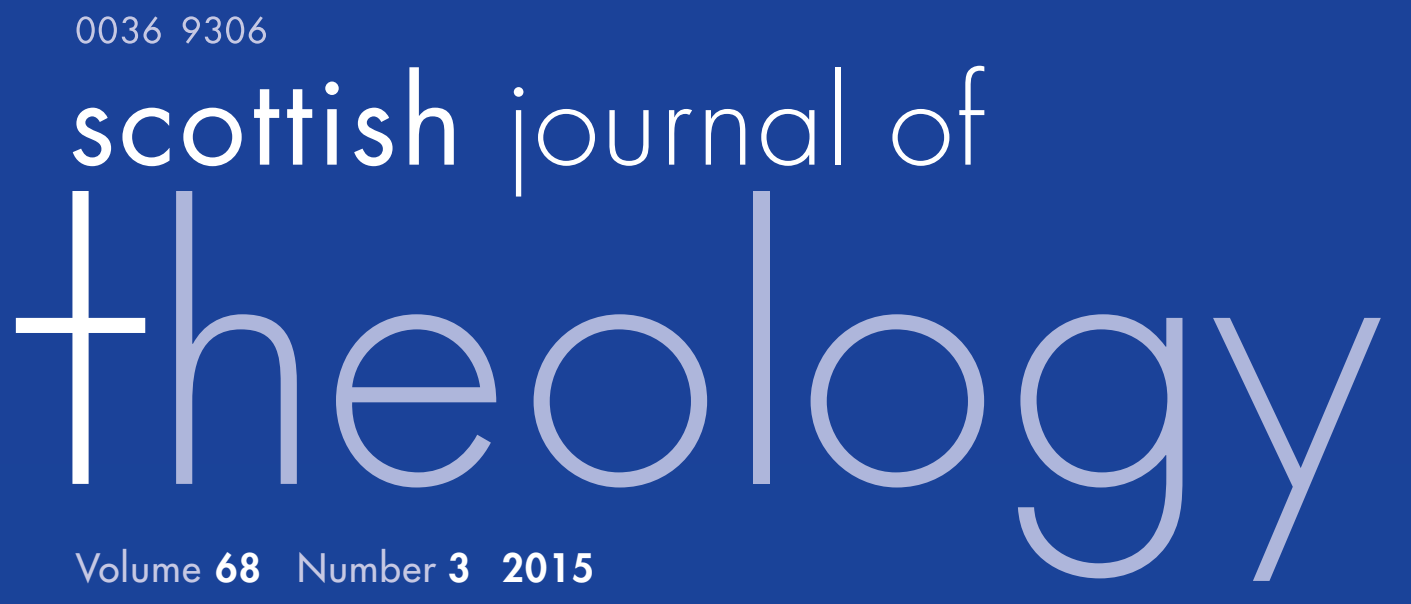




\section{Iain Torrance}

University of Edinburgh, UK

Email: sjt@ed.ac.uk

\section{Editorial associate}

Morag Torrance

Email: sjt@ed.ac.uk

\section{Consulting Editors}

\section{James Edwards}

Whitworth University, Spokane, Washington, USA

\section{David Fergusson}

University of Edinburgh, Scotland, UK

David Ford

University of Cambridge, UK

Stanley Hauerwas

The Divinity School, Duke University, USA

Paul Joyce

King's College, London, UK

Lois Malcolm

Luther Seminary, St Paul, USA

Joseph Mangina

Wycliffe College, Toronto, Canada

\section{Bruce L. McCormack}

Princeton Theological Seminary, New Jersey, USA

\section{Ian A. McFarland}

Emory University, Atlanta, USA

\section{Paul Molnar}

St John's University, Queens, New York, USA

\section{Bryan Spinks}

Yale University, USA

Email: bryan.spinks@yale.edu

\section{Amy Plantinga Pauw}

Louisville Presbyterian Theological Seminary, Louisville, Kentucky, USA

Kang Phee Seng

China Graduate School, Hong Kong

\section{F. LeRon Shults}

University of Agder, Institute for Religion, Philosophy and History, Kristiansand, Norway

\section{Kathryn Tanner}

Yale Divinity School, Yale, USA

\section{Leanne Van Dyk}

Western Theological Seminary, Holland, Michigan, USA

\section{Dawn DeVries}

Union Theological Seminary, Richmond, Virginia, USA

\section{John Webster}

University of St Andrews, Scotland, UK

\section{Michael Weinrich}

University of Bochum, Germany

Scottish Journal of Theology is published by Cambridge University Press on behalf of Scottish Journal of Theology Ltd, an independent company registered in Scotland and recognised as a Charity, under the control of its own Board of Directors. Scottish Journal of Theology Ltd is a Charity registered in Scotland, SC000435.

\section{Subscriptions}

Scottish Journal of Theology (ISSN 0036-9306; electronic ISSN 1475-3065) is published four times a year in February, May, August and November. Four parts form a volume. The subscription price which includes delivery by air where appropriate (but excluding VAT) of volume 68 is $£ 163$ (US $\$ 293$ in USA, Canada and Mexico) for institutions (print and electronic); $£ 146$ (US \$262) for institutions (electronic only); $£ 34$ (US \$57) for individuals ordering direct from the publishers and certifying that the journal is for their personal use (print only); £26 (US \$42) for members of the American Academy of Religion, the Society for Biblical Literature, or the Society for the Study of Theology (print only). Single parts are $£ 45$ net (US \$81 in USA, Canada and Mexico) plus postage. EU subscribers (outside the UK) who are not registered for VAT should add VAT at their country's rate. VAT registered members should provide their VAT registration number. Japanese prices for institutions (including ASP delivery) are available from Kinokuniya Company Ltd, P.O. Box 55, Chitose, Tokyo 156, Japan.

Orders, which must be accompanied by payment, may be sent to a bookseller, subscription agent or direct to the publisher: Cambridge University Press, Journals Fulfilment Department, UPH, Shaftesbury Road, Cambridge CB2 8BS, UK; or in the USA, Canada and Mexico: Cambridge University Press, Journals Fulfillment Department, 100 Brook Hill Drive, West Nyack, New York 10994-2133. Application to mail at periodicals postage rates is pending at New York, NY.

\section{Internet Access}

Scottish Journal of Theology is included in the Cambridge Journals Online service which can be found at journals.cambridge.org. Further information on SJT can be found at http://www.ed.ac.uk/sjt/ For information on other Cambridge titles access http://www.cambridge.org

(C) Scottish Journal of Theology Ltd 2015

Printed in the UK by Bell \& Bain Ltd., Glasgow. 


\section{Contents}

253 Editorial

Articles

255 Revisiting Karl Barth's doctrine of baptism from a perspective on prayer Ashley Cocksworth

273 On patience: thinking with and beyond Karl Barth Paul Dafydd Jones

299 'Offenbarung, Philosophie, und Theologie': Karl Barth and Georges Florovsky in dialogue Matthew Baker

327 An undefensive presence: the mission and identity of the church in Kathryn Tanner and John Howard Yoder Brad East

Article reviews

345 Christopher Beeley, The Unity of Christ Paul L. Gavrilyuk

351 Christopher Beeley, The Unity of Christ Brian E. Daley

Response

356 Response to Brian Daley and Paul Gavrilyuk on The Unity of Christ Christopher A. Beeley

Book reviews

366 Michael DeJonge, Bonhoeffer's Theological Formation: Berlin, Barth and Protestant Theology

368 Michael J. McClymond and Gerald R. McDermott (eds), The Theology of Jonathan Edwards

370 Nicholas Wolterstorff, The Mighty and the Almighty: An Essay in Political Theology

372 Leslie J. Francis and Mandy Robbins (eds), Rural Life and Rural Church: Theological and Empirical Perspectives

375 Johnston McKay, The Kirk and the Kingdom: A Century of Tension in Scottish Social Theology, 1830-1929 